\title{
Automicrites in modern cyanobacterial stromatolitic deposits of Rangiroa, Tuamotu Archipelago, French Polynesia: Biochemical parameters underlaying their formation
}

\author{
Pascale Gautret and Jean Trichet
}

Institut des Sciences de la Terre d'Orleans (ISTO), Université d'Orléans, UMR $6113 \mathrm{du}$ CNRS, Bât. Géosciences, F-45067 Orléans Cedex, France

\section{Abstract}

This paper provides evidence of the role of the proteinaceous constituents of the sedimentary organic matter in the control of $(\mathrm{Ca}, \mathrm{Mg})$ carbonate precipitation within recent stromatolitic sediments belonging to the kopara-type (Rangiroa, Tuamotu Archipelago, French Polynesia). Millimeter- to $\mathrm{cm}$-thick alternating carbonate-rich and carbonate-poor layers allow the separation by hand of these two contrasted types of layers (with respect to carbonate content). The study aims, (1) to decipher the potential compartments (cyanobacterially derived and dissolved organic matter) for proteins that interact with divalent cations, to compare their biochemical composition with those of the intramineral organic matrices that incorporate fine authigenic micrites when they form; (2) to discriminate the ageing processes of organic matter, including $\mathrm{OM}$ mineralized by $\mathrm{CaCO}_{3}$; (3) to correlate the biochemical features of protein-rich molecules dissolved in natural pore waters, extracted from different sediment layers (either carbonate-rich or carbonate-poor), with experimental tests of the efficiency of these same protein-rich molecules in the role of calcium carbonate inhibitors. The extracted natural macromolecules definitely control the rate of in vitro calcium carbonate precipitation: they exert an inhibiting effect, which strength depends on the type of layer-carbonate-rich or carbonate-poor-out of which they have been extracted. The quality (with respect to their aspartic and/or glutamic acid contents), as well as the amount of soluble protein-rich macromolecules present in the pore waters in each layer, plays a key role in active calcification processes. As a matter of fact, pore waters of carbonate-poor layers deliver high concentrations of dissolved, aspartic-rich macromolecules that are shown to inhibit strongly calcium carbonate precipitation in experimental conditions.

The consequence of such experimentally based results, as well as the correlation with the actual intensity of calcification in natural sediment layers, is crucial for discussing calcium carbonate balance or the formation of laminations in paleoenvironments.

Keywords: Laminated sediment; Cyanobacterially derived organic matter; Amino acids; Organomineralization; Calcium carbonate precipitation; Inhibition 


\section{Introduction}

Calcification in cyanobacterial mats is very common from the Precambrian to the Recent, in many types of environments, varying from fresh to hypersaline waters, deep to shallow habitats, and low to high energy. In situ precipitation of calcium carbonate in modern cyanobacterially derived organic matter is a widely documented field, since it is recognized as an important contributor in the formation of microbialites and stromatolites (e.g., Golubic, 1973, Golubic, 1976, Krumbein et al., 1977, Krumbein, 1979, Burne and Moore, 1987, Riding, 1991 and Reid and Browne, 1991), in addition to other "trapping and binding" processes (Logan et al., 1964 and Davies, 1970). However, in spite of such a large interest, it is difficult to find consensual models relevant to the processes of calcification and organomineral interactions involved. The simplest reason for this is most probably that there is no single model of microbialite formation, which can be possibly a highly convergent fabric.

The study presented in this paper was carried out on modern laminated "kopara type" deposits that have already provided significant evidence of the roles that microbial, cyanobacterially derived organic substrates play in authigenic carbonate precipitation (Défarge et al., 1993, Défarge et al., 1994a, Défarge et al., 1994b and Défarge et al., 1996). Several properties of these organic substrates have been shown to facilitate calcium carbonate precipitation: negatively charged, potentially Ca-binding sites at the surface of organic substrates, such as uronic acids and the carboxyl groups of acidic amino acids, or sulfates supported by polysaccharides (Disnar and Trichet, 1981). In kopara deposits, the increase of $\mathrm{Ca}^{2+}$ or $\mathrm{HCO}_{3}{ }^{-}$ concentration, for example through the decomposition of $\mathrm{Ca}^{2+}, \mathrm{Mg}^{2+}$-organic complexes (Trichet, 1967), or through the mixing with external solutions (such as phreatic reef solutions) already rich in $\mathrm{Ca}$ or $\mathrm{Ca}$ and $\mathrm{Mg}$ (Trichet, 1967) also enhances precipitation of calcium carbonate. Additionally in other microbial environments, calcification is known to develop preferentially in close relationship with degrading cyanobacterial mats (e.g., Greenfield, 1963, Monty, 1965 and Trichet and Défarge, 1995), as in a wide variety of ecosystems in the presence of decaying tissues (e.g., Berner, 1969 and Sagemann et al., 1999). An explanation in which the $\mathrm{pH}$ rise of solutions in contact with decaying organisms, as well as in decaying cyanobacterial mats, due to the formation of ammonia and basic amines derived from protein breakdown (Berner, 1968 and Berner, 1969), can be reasonably envisaged. Other factors considered to promote calcification result from the metabolic activity by microbes, such as the decrease of $\mathrm{pCO}_{2}$ within solutions under a photosynthetic demand (Thompson and Ferris, 1990, Merz, 1992 and Merz et al., 1995), the increase of $\mathrm{Ca}^{2+}$ or $\mathrm{HCO}_{3}{ }^{-}$concentration owing to the expulsion of intracellular $\mathrm{Ca}^{2+}$ or $\mathrm{CO}_{2}$ out of the cell (Thompson and Ferris, 1990 and Yates and Robbins, 1999), or sulfate reduction resulting from microbial activity and leading to the release of $\mathrm{HCO}_{3}{ }^{-}$in the solution (Visscher et al., 2000).

Another concept of interest for the understanding of calcification in natural environments is based on the evidence that soluble and pseudo-soluble organic compounds can be inhibitors for calcium carbonate precipitation in organic-rich waters. The term "anti-calcification" is used by Westbroek et al. (1994) to denote the active biological inhibition of random carbonate mineral crystallization in highly supersaturated micro-environments. In this situation, calcium carbonate formation is a consequence of particular conditions fulfilled only when biologically driven, anti-calcification factors are removed. Also in estuarine environments, the organic load within the interstitial solution is considered a determinant factor in the inhibition of calcium carbonate precipitation (Tipping, 1994, Lebron and Suarez, 1996, Lebron and Suarez, 1998 and Hoch et al., 2000). The same effect is known from organic matrices associated with biogenic carbonates produced by many taxonomic groups (Wheeler et al., 1981, Borman et 
al., 1982, Gautret, 2000 and Gautret, 2001), with the commonly accepted explanation that the calcium-binding ability of selected organic compounds leads to the formation of organic coatings on newly formed mineral surfaces, which prevent further crystal growth (e.g., Addadi et al., 2001).

In situ observations of the occurrence or non-occurrence of calcium carbonate formation in the microbial environments of alkaline lakes support the anti-calcifying role of extracellular polymeric substances (EPS) produced by biofilm-forming microbial cells (Arp et al., 1998 and Arp et al., 1999). According to the authors, EPS has a Ca-buffering effect allowing $\mathrm{CaCO}_{3}$ microbialite formation only when the buffering capacity by the organic mucilages is exceeded.

The aim of this paper is to provide evidence of the role of the protinaceous constituents of the sedimentary organic matter in the control of $(\mathrm{Ca}, \mathrm{Mg})$ carbonate precipitation in modern stromatolitic sediments belonging to the kopara-type. Alternating carbonate-rich and carbonate-poor layers $\mathrm{mm}$ to $\mathrm{cm}$ thick can be hand separated. Our study is oriented at (1) comparing the amino-acid compositions and physical status (soluble/insoluble) of the organic matter in four components in which this composition is thought to influence calcium carbonate precipitation: sedimentary and dissolved organic matter, external to carbonate minerals and intramineral, soluble and insoluble OM; (2) discriminating the processes of the degradation of organic matter, both out and in carbonate minerals; (3) correlating the biochemical characteristics of protein-rich molecules dissolved in natural pore waters extracted from different sediment layers (either carbonate-rich or -poor), with experimental tests of the efficiency of these same protein-rich molecules as inhibitors of calcium carbonate precipitation.

In previous studies, kopara sediments could not be separated and analyzed owing to the much finer thickness and poor regularity (Défarge and Trichet, 1985) of carbonate-rich and -poor layers. For this reason, previous analyses gave insight only on the properties of the bulk organic matter associated with stromatolitic kopara sediments.

\section{Study area}

The atoll of Rangiroa is located N-W of the Tuamotu archipelago, in French Polynesia (Fig. 1A). It is the largest atoll in the archipelago $(78 \mathrm{~km} \times 30 \mathrm{~km})$. The islets emerge generally 2 to $3 \mathrm{~m}$ above sea level and bear small ponds (ca. some tens of meters in diameter) containing brackish waters ( $0 \%$ to $41 \%$ salinity in studied kopara ponds) that are infilled with "kopara", i.e., an organo-mineral sediment, resulting from the decay of cyanobacterial bodies and authigenic precipitation of high-Mg calcite ( 7 to 19 moles $\mathrm{MgCO}_{3}$, in most kopara deposits), or, more rarely, aragonite (Défarge et al., 1996). 

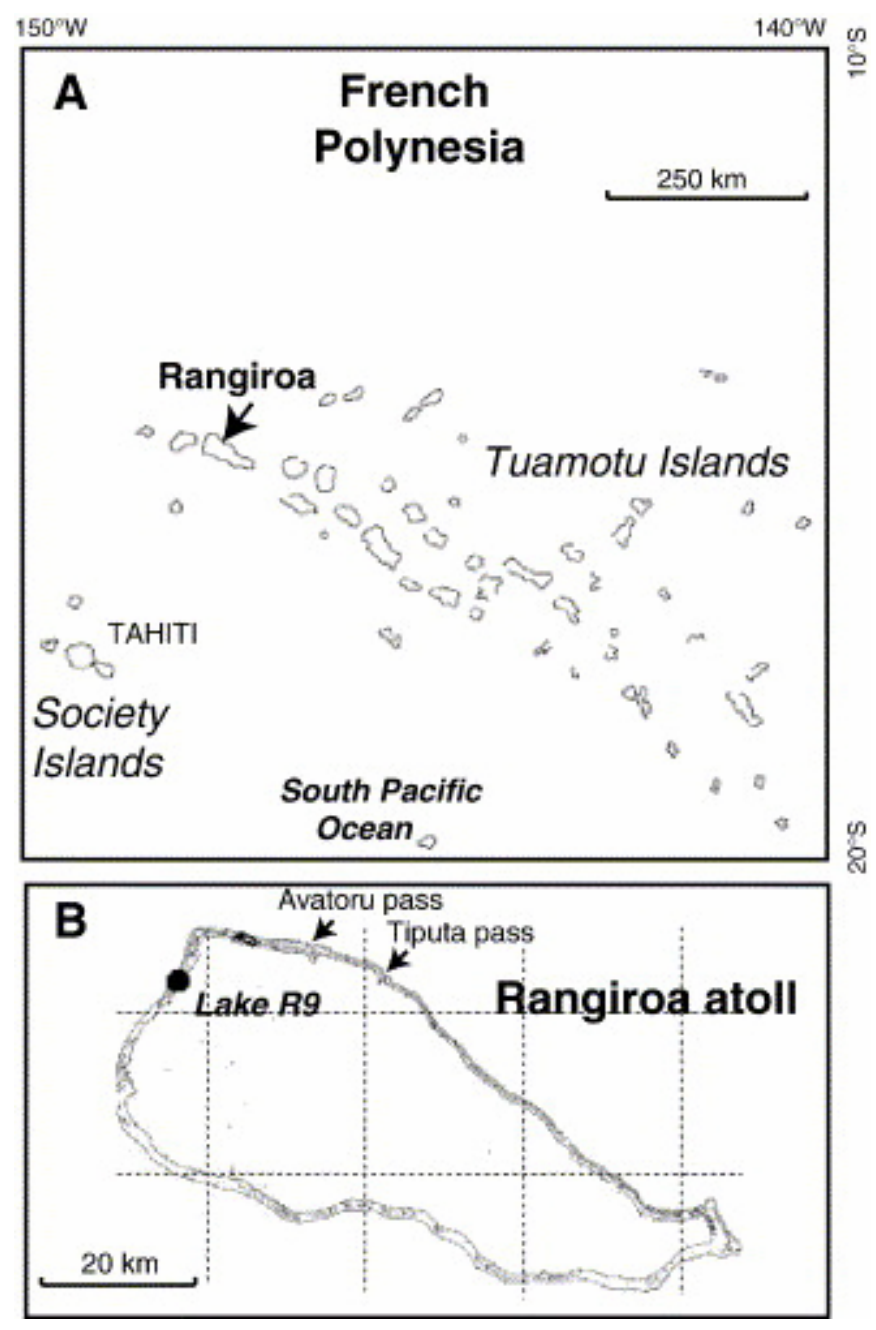

Fig. 1. Location map of the studied pond R9, Rangiroa atoll, Tuamotu Archipelago, French Polynesia.

Pond R9 is located in the N-W part of the atoll (Fig. 1B). The water salinity in this pond ranges from 20 to 38 ppt (Rougeaux et al., 2001). It contains a quasi-emerged external part where the microbial sediments, approximately $30 \mathrm{~cm}$ thick, are horizontal and continuous, and an internal, underwater (ca. $30 \mathrm{~cm}$ deep) part, in which well individualized, round-headed bodies (Fig. 2A, B) result from the dissection by currents of sediments similar to the continuous external sediments. 

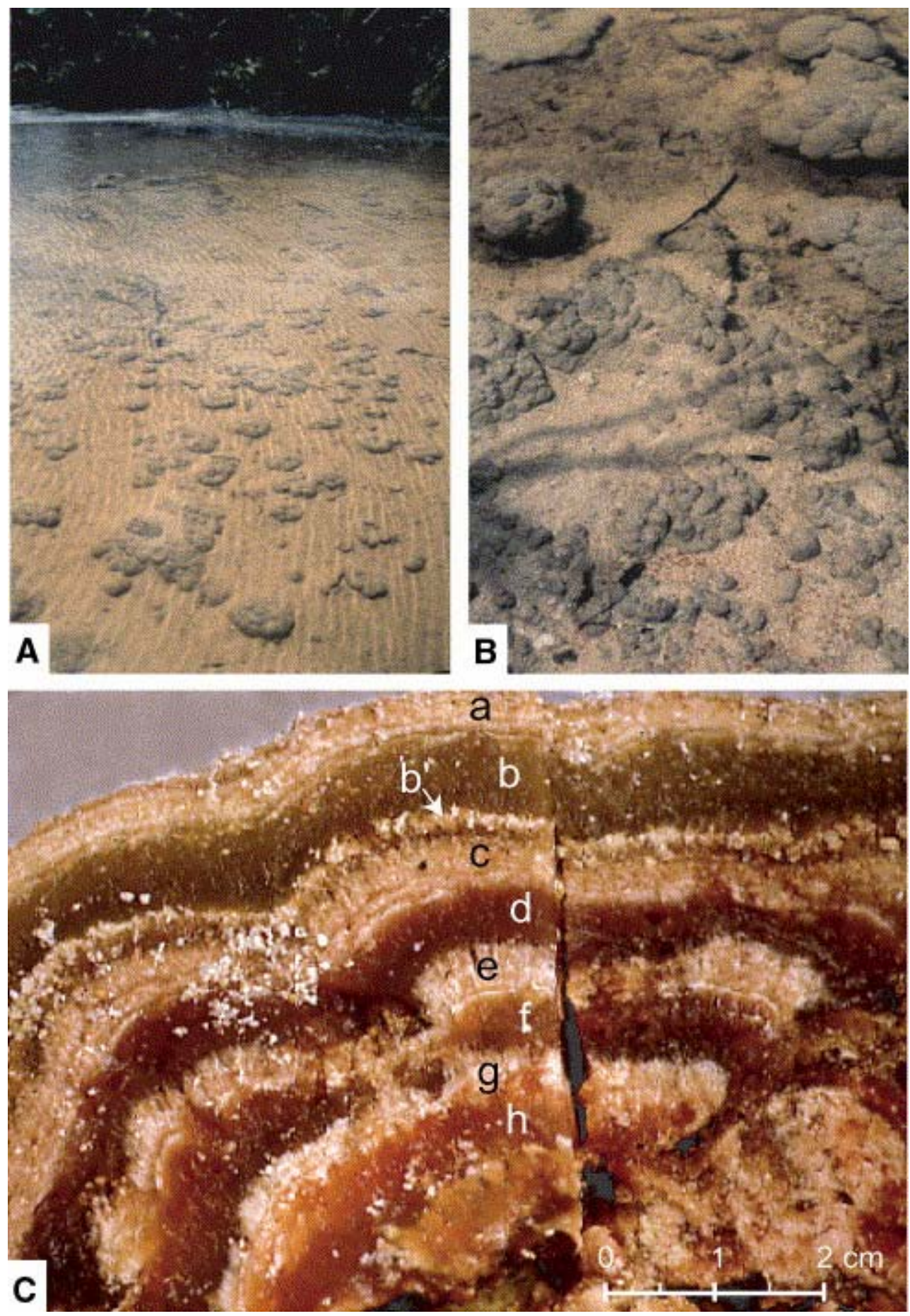

Fig. 2. (A) Internal part of pond R9, showing underwater (ca. $30 \mathrm{~cm}$ deep), well individualized, round-headed bodies. (B) Enlarged view of individualized bodies, resulting from the dissection by currents of sediments, similar to continuous sediments in the external part of the pond. (C) Section of the studied sediment: $5 \mathrm{~cm}-\mathrm{high}$ top part of a well individualized, round-headed body showing the alternation of sub-concentric, colored layers (greenish layer b; reddish $\mathrm{d}, \mathrm{f}, \mathrm{h}$ ) and whitish layers (a, c, e, g). The former are poor in carbonate precipitates, the latter are rich. (For interpretation of the references to colour in this figure legend, the reader is referred to the web version of this article.) 


\section{Material and methods}

The successive layers of the stromatolite shown in Fig. 2C were scalpel cut and each was prepared for providing separate samples of sedimentary organic matter, pore water, and purified carbonates.

\subsection{Separation of sedimentary organic matter}

Sediment pieces were repeatedly mixed and decalcified with $0.6 \mathrm{~N} \mathrm{HCl}$ in order to remove the carbonates. The residue was rinsed with MilliQ water at $\mathrm{pH}_{\sim 6} 6$, then lyophilized.

\subsection{Separation of organic macromolecules dissolved in pore waters}

Pore waters were extracted by centrifugation of sediment subsamples. They were filtered $(0.45 \mu \mathrm{m})$, desalted by ultrafiltration against MilliQ water (Filtron $3 \mathrm{kDa}$, desalting controlled by conductimetry), and lyophilized.

\subsection{Separation of purified carbonates}

Sediment subsamples were repeatedly mixed in Na hypochlorite in order to disaggregate most of the organic matter in which the carbonate aggregates were entrapped (see pictures in Défarge et al., 1994a, Défarge et al., 1994b and Défarge and Trichet, 1995). The suspension (of carbonate grains within a residual organic matter) was repeatedly centrifuged and resuspended in order to obtain some grams (out of carbonate-rich layers) or milligrams (out of carbonate-poor layers) of purified carbonates. Carbonate particles were sorted according to grain size and the finest, less than $50 \mu \mathrm{m}$, fraction size was kept for analysis. Sieving $(>50$ $\mu \mathrm{m})$ removed the biodetrital, sandy sized, allochtonous particles that could have been introduced in the pond during climatic or tide events. The fine fraction retained for analysis is composed of aggregates of very fine, nanometer-sized, individual Mg-calcite minerals (see pictures in Défarge et al., 1994a, Défarge et al., 1994b and Défarge and Trichet, 1995).

\subsection{Separation of soluble and insoluble organic matrices associated with fine-grained carbonates}

Fine-grained carbonates were decalcified overnight with acetic acid (pH4 automatically controlled). Solutions were centrifuged and the supernatant containing soluble organic matrices (SOM) were desalted by gel filtration chromatography with a Pharmacia G25C column (detection: UV $280 \mathrm{~nm}$ and conductimetry). The SOM were then ultrafiltered (Filtron $3 \mathrm{~K}$ ) with MilliQ water, and lyophilized. The residue of centrifugation contains the insoluble organic matrices (IOM).

\subsection{Amino-acid analysis}

The amino-acid composition of the lyophilized organic samples was determined after $24 \mathrm{~h}$, $110{ }^{\circ} \mathrm{C}, 6 \mathrm{~N} \mathrm{HCl}$ hydrolysis under $\mathrm{N}_{2}$ atmosphere and phenyl-isothiocyanate (PITC) derivatisation by Reverse Phase Chromatography on Hypersil C18 $5 \mu \mathrm{m}$ column, with acetonitrile gradient. The molecular composition was obtained by calculations using peak areas provided by the analyzed solution and the Beckman amino acid calibration kit. 
The total amount of soluble proteinaceous compounds (expressed in $\mu \mathrm{g} / \mathrm{g}$ fine-grained carbonate or in $\mu \mathrm{g} / \mathrm{ml}$ solutions) were obtained by adding the weights of individual amino acids within the samples.

The weight of proteinic carbon atoms can be calculated by adding all carbon atoms provided by individual amino acids, and calculated as a percentage of total soluble organic carbon.

The total soluble organic carbon in centrifuged solutions was obtained by combustion in an automatic (CNHS) autoanalyzer.

\subsection{In vitro-tests of the influence of organic compounds on $\mathrm{CaCO}_{3}$ precipitation rate}

The influence of the amount and of the nature of macromolecules dissolved in pore waters on the rate of calcium carbonate precipitation was tested with an experimental protocol comparable to that used by Wheeler et al. (1981), Borman et al. (1982), and Gautret, 2000 and Gautret, 2001 as follows. A known amount of lyophilized organic compound was added to 3 $\mathrm{ml}$ of $30 \mathrm{mM} \mathrm{NaHCO}$. An electrode connected to a recorder was introduced in the tube giving a permanent control of $\mathrm{pH}$ variations throughout the test $(\mathrm{pH}$ 8.5-8.6 at initial conditions). Three milliliters of $30 \mathrm{mM} \mathrm{CaCl}_{2}$ were rapidly added, causing instantaneous shift of the $\mathrm{pH}$ down to 8-8.2. The following $\mathrm{pH}$ variations resulted from the release of hydrogen ions when sodium chloride was formed and calcium carbonate precipitated. A blank test with salt solutions only, i.e., without added organic compounds, showed carbonate precipitation starting immediately, and ending in very short time (not more than 2 or $3 \mathrm{~min}$ ), with $\mathrm{pH}$ values stabilizing around 7.3-7.4. A delay in $\mathrm{pH}$ decrease in the presence of organic constituents is considered an indication of inhibition of $\mathrm{CaCO}_{3}$ precipitation.

\section{Results}

Fig. 2C shows a section of the sample from the internal, underwater part of pond R9 used for our analyses. This section exhibits the alternation of sub-concentric, colored layers (greenish layer b; reddish d, f, h) and whitish layers (a, c, e, g). The colored layers do not contain large amounts of in-situ precipitated calcium carbonate and are hereafter called "carbonate-poor layers". They are composed of microbially derived organic matter (sedimentary OM) and their colors are due to the presence of carotenoidic pigments derived from both cyanobacteria (living at the surface of the head, in a 2-3 $\mathrm{mm}$ thick layer) and sulfur-oxidizing photosynthetic purple bacteria that develop between the top cyanobacterial layer and the deeper sedimentary layers (Trichet and Défarge, 1999). The whitish layers are rich in precipitated carbonates, dispersed throughout the same, microbially derived organic matter as in the colored layers. They are called "carbonate-rich layers" in the following. One thin (1-2 $\mathrm{mm}$ ) layer, named $\mathrm{b}^{\prime}$ in Fig. $2 \mathrm{C}$ corresponds to detrital biogenic sands that have been introduced into the pond from the lagoonal beach during a storm or a high tide. The individual thickness of both carbonate-rich and carbonate-poor layers is 0.5 to $1 \mathrm{~cm}$. The analyses reported in this paper have been performed on those seven layers, a to g, excluding b'.

In each individual layer a to $\mathrm{g}$ (see section, Fig. 2C), relative amino-acid compositions and occasionally total amino-acid contents were determined in the organic matter of four components in which this composition is thought to influence calcium carbonate precipitation: 
sedimentary (Table 1) and dissolved (Table 2) organic matter, external to carbonate minerals and intramineral, soluble (Table 4) and insoluble (Table 5) organic matrices.

Table 1. : Amino-acid composition (residues \%) of the sedimentary, cyanobacterially derived organic matter in alternating carbonate-rich (a, c, g, e) and carbonate-poor (b, d, f $+\mathrm{h}$ ) layers (see Fig. 2C)

\begin{tabular}{|l|c|c|c|c|c|c|c|}
\hline & \multicolumn{7}{|c|}{ Sediment layers } \\
\hline & $\mathbf{a}$ & $\mathbf{b}$ & $\mathbf{c}$ & $\mathbf{d}$ & $\mathbf{e}$ & $\mathbf{f}+\mathbf{h}$ & $\mathbf{g}$ \\
\hline Asp & 12.85 & 15.38 & 15.39 & 12.72 & 15.48 & 15.55 & 16.40 \\
\hline Glu & 10.27 & 10.24 & 9.74 & 7.76 & 7.82 & 7.89 & 8.24 \\
\hline Lys & 0.96 & 0.06 & 0.69 & 1.86 & 3.36 & 3.53 & 3.31 \\
\hline Arg & 5.75 & 5.66 & 5.31 & 4.31 & 4.10 & 3.93 & 3.88 \\
\hline His & 7.26 & 8.02 & 6.95 & 6.20 & 5.54 & 6.39 & 6.06 \\
\hline Gly & 12.63 & 13.45 & 13.10 & 11.96 & 10.17 & 10.23 & 10.11 \\
\hline Ala & 10.75 & 15.51 & 14.58 & 14.86 & 11.66 & 12.19 & 11.69 \\
\hline Val & 8.22 & 7.94 & 8.19 & 7.87 & 8.79 & 8.98 & 9.23 \\
\hline Leu & 8.33 & 5.66 & 6.99 & 9.00 & 9.98 & 7.95 & 7.92 \\
\hline Ile & 5.93 & 3.94 & 4.56 & 6.27 & 6.29 & 5.96 & 5.94 \\
\hline Ser & 4.75 & 6.09 & 5.85 & 6.54 & 5.23 & 5.08 & 5.51 \\
\hline Thr & 0.81 & 0.35 & 0.32 & 0.00 & 0.35 & 0.17 & 0.00 \\
\hline Pro & 2.01 & 1.88 & 1.92 & 1.84 & 2.09 & 2.07 & 2.08 \\
\hline Tyr & 1.59 & 0.97 & 1.17 & 1.55 & 1.57 & 1.59 & 1.53 \\
\hline Phe & 7.90 & 4.84 & 5.25 & 7.27 & 7.58 & 8.48 & 8.11 \\
\hline
\end{tabular}


Table 2. : Amino-acid composition (residues \%) of dissolved macromolecules ( $\mathrm{MW}>3 \mathrm{kDa}$ ) purified out of pore waters in alternating carbonate-rich (a, c, g, e) and carbonate-poor (b, d, f) layers (see Fig. 2C)

\begin{tabular}{|c|c|c|c|c|c|c|c|}
\hline & \multicolumn{7}{|c|}{ Sediment layers } \\
\hline & $\mathbf{a}$ & b & c & d & $\mathbf{e}$ & $\mathbf{f}$ & g \\
\hline Asp & 10.80 & 14.68 & 12.72 & 14.90 & 14.36 & 6.21 & 12.28 \\
\hline Glu & 11.20 & 11.24 & 11.03 & 10.92 & 10.55 & 10.77 & 12.22 \\
\hline Lys & 2.29 & 2.35 & 2.14 & 1.84 & 2.58 & 2.73 & 2.30 \\
\hline Arg & 1.87 & 1.68 & 1.62 & 1.45 & 1.23 & 1.33 & 0.96 \\
\hline His & 1.49 & 1.38 & 1.65 & 1.68 & 1.22 & 1.67 & 1.13 \\
\hline Gly & 11.42 & 10.87 & 12.14 & 12.43 & 11.55 & 15.08 & 17.46 \\
\hline Ala & 13.01 & 12.37 & 13.29 & 14.63 & 13.61 & 13.25 & 10.63 \\
\hline Val & 9.45 & 8.89 & 8.72 & 7.93 & 8.00 & 8.58 & 5.01 \\
\hline Leu & 10.35 & 9.48 & 9.34 & 9.00 & 9.15 & 9.49 & 5.55 \\
\hline Ile & 6.70 & 6.19 & 6.02 & 5.48 & 5.67 & 5.84 & 2.55 \\
\hline Ser & 6.10 & 4.96 & 6.81 & 7.32 & 7.78 & 7.71 & 10.65 \\
\hline Thr & 0.59 & 0.16 & 0.00 & 0.47 & 0.56 & 1.34 & 1.39 \\
\hline Pro & 4.08 & 3.63 & 3.92 & 3.87 & 4.11 & 3.54 & 2.45 \\
\hline Tyr & 3.57 & 2.97 & 3.42 & 2.01 & 2.17 & 2.00 & 1.28 \\
\hline Phe & 5.29 & 7.32 & 6.10 & 5.64 & 7.02 & 9.54 & 10.01 \\
\hline
\end{tabular}

\subsection{Nature and amounts of amino acids within the organic matter of sediment fractions}

\subsubsection{Sedimentary organic matter}

Amino-acid compositions (Table 1) display strong similarities in sedimentary organic matter of the seven layers analyzed (organic matter of layers $\mathrm{f}$ and $\mathrm{h}$ were combined because of the lack of material). Aspartic acid (12.7-16.4\%), alanine (10.7-15.5\%), and glycine (10.1$13.5 \%$ ) are the dominant residues, followed by glutamic acid $(7.8-10.3 \%)$, valine $(7.9-9.2 \%)$, leucine $(5.7-10 \%)$, histidine (5.6-8\%), phenylalanine (4.8-8.5\%), and isoleucine (4-6.3\%).

\subsubsection{Pore waters}

The molecular amino-acid composition of dissolved macromolecules isolated from pore waters (Table 2) is dominated by glycine (10.9-17.5\%), alanine (10.6-14.3\%), aspartic acid $(6.2-14.7 \%)$, glutamic acid (10.5-12.2\%), serine (4.5-10.6\%), and phenylalanine $(5.2-10 \%)$. Compared to the sedimentary organic matter, pore waters are enriched in glutamic acid, 
serine, proline and tyrosine, and depleted in aspartic acid. The macromolecules contain only very low concentrations of arginine and histidine ( $2 \%$ or less).

The variations of relative amino-acid compositions are not very important among the different layers, except within the deepest one $(\mathrm{g})$ where the pore water is characterized by the highest concentrations of Gly, Ser, Phe, Glu, and Thr, and the lowest ones of Ala, Val, Leu, Ile, Pro, Tyr, Arg, and His.

Table 3 and Fig. 3 show the total organic carbon (TOC) content and the weight of proteinaceous compounds dissolved in the pore waters extracted out each of the seven sediment layers, as well as the organic carbon content associated with amino acids. A very high discrepancy exists between the total dissolved organic carbon and the protein-associated carbon. This means that, from a quantitative point of view, most of the organic matter in the pore waters is not proteinaceous. Non-proteinaceous carbon belongs to organic molecules whose biochemical nature is only partly known. The quantities of proteinaceous compounds exhibit alternatingly high and low values in correlation with the intensity of carbonatation within the layer (Table 3, Fig. 3).

Table 3. : Organic carbon and proteinaceous compounds in pore waters and in carbonate precipitates within alternating carbonate-rich (a, c, g, e) and carbonate-poor (b, d, f) layers (see Fig. 2C)

\begin{tabular}{|l|l|l|l|l|l|l|}
\hline Sediment layers & \multicolumn{3}{|l}{ Pore waters } & \multicolumn{2}{l|}{ Carbonates } \\
\hline & TOC & DMM & \multicolumn{2}{|l}{ DMM-provided C } & IOM & SOM \\
\hline & $(\mathbf{m g} / \mathbf{l})$ & $\mathbf{( m g / l )}$ & $\mathbf{( m g / l )}$ & $\mathbf{( \% )}$ & $(\boldsymbol{\mu g} / \mathbf{g})$ & $(\boldsymbol{\mu g} / \mathbf{g})$ \\
\hline a & $\mathbf{4 4 8 . 6}$ & $\mathbf{6 6 . 2}$ & $\mathbf{3 4 . 0}$ & $\mathbf{4 6}$ & $\mathbf{6 4 . 6}$ & $\mathbf{1 1 . 0}$ \\
\hline b & 413.1 & 102.7 & 51.5 & 46 & 54.3 & 402.5 \\
\hline c & $\mathbf{2 2 9 . 0}$ & $\mathbf{2 7 . 5}$ & $\mathbf{1 3 . 8}$ & $\mathbf{4 6}$ & $\mathbf{1 1 . 3}$ & $\mathbf{3 8 . 9}$ \\
\hline d & 253.0 & 59.0 & 27.6 & 45 & 251.3 & 146.2 \\
\hline e & $\mathbf{2 2 0 . 5}$ & $\mathbf{4 4 . 8}$ & $\mathbf{2 0 . 5}$ & $\mathbf{4 6}$ & $\mathbf{2 3 . 2}$ & $\mathbf{5 5 . 4}$ \\
\hline f & 150.9 & 25.4 & 12.4 & 47 & $988.5(?)$ & 41.5 \\
\hline g & $\mathbf{1 6 4 . 0}$ & $\mathbf{5 . 1}$ & $\mathbf{2 2 . 6}$ & $\mathbf{4 5}$ & $\mathbf{7 4 . 2}$ & $\mathbf{3 4 . 0}$ \\
\hline
\end{tabular}

Bold characters refer to carbonate-rich layers.

TOC (mg/l), total organic carbon atoms in pore waters; DMM $(\mathrm{mg} / \mathrm{l})$, dissolved macromolecules in pore waters; DMM-derived C (mg/l and \%), weight and percentage of carbon atoms calculated according to the amino-acid composition of individual dissolved macromolecules; IOM $(\mu \mathrm{g} / \mathrm{g})$, weight of intramineral insoluble organic matrix per gram of carbonate; SOM $(\mu \mathrm{g} / \mathrm{g})$, weight of intramineral soluble organic matrix per gram of carbonate. 


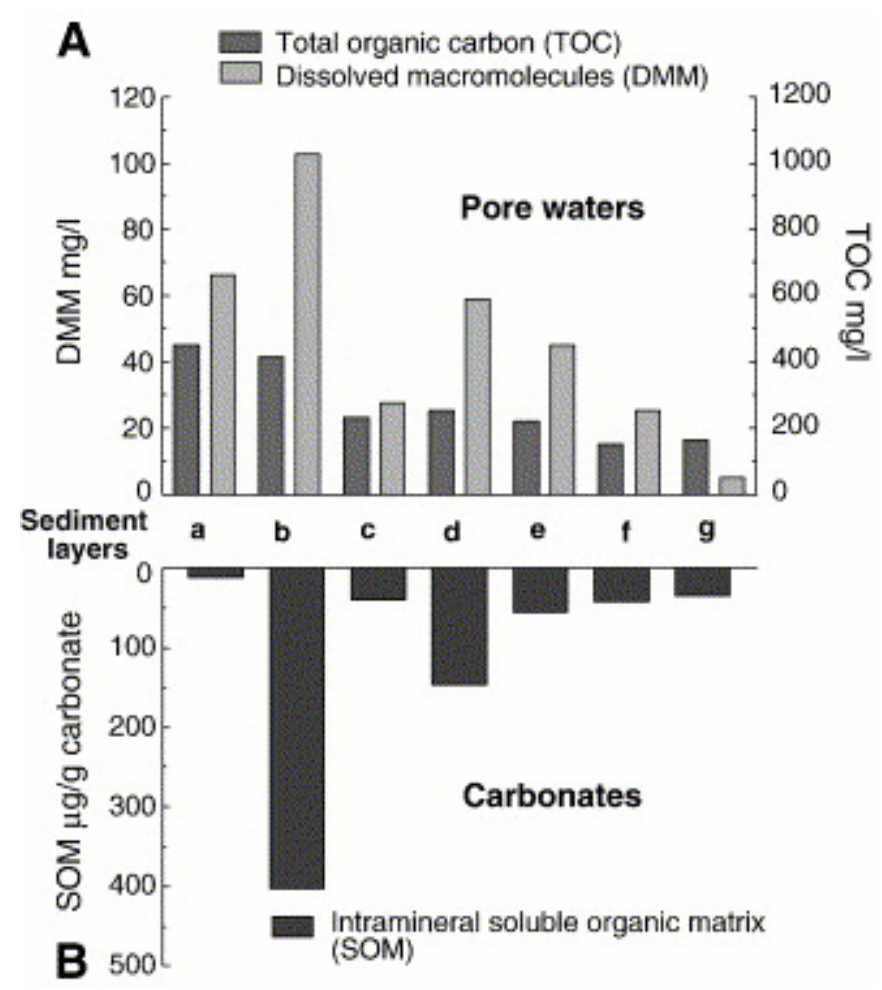

Fig. 3. (A) Amounts of dissolved, high molecular weight proteins (MW $>3 \mathrm{kDa})(\mathrm{mg} / \mathrm{l})$ and total organic carbon $(\mathrm{mg} / \mathrm{l})$ in pore waters. (B) Amounts of proteinaceous compounds in SOM extracted from carbonates $(\mu \mathrm{g} / \mathrm{g}$ carbonate). TOC: Total organic carbon; DMM: Dissolved organic macromolecules in pore waters; SOM: Intramineral soluble organic matrix.

\subsubsection{Carbonates}

Table 3 (right) lists the amounts of proteinaceous compounds in the intramineral organic matrix, in insoluble and soluble fractions respectively. The calculated weight of amino acids in the soluble matrix, expressed as $\mu \mathrm{g}$ per gram of carbonate, varies strongly among the successive layers with a concentration pattern parallelling the total amino-acid content in pore waters (Table 3, Fig. 3). The total amount of bulk proteinaceous compounds in the insoluble intramineral organic fraction does not show such a systematic variation.

Soluble matrices extracted from the carbonates (Table 4) reveal relatively homogeneous compositional spectra, dominated first by glycine (12.9-18.2\%), and glutamic acid (12.2$21.1 \%)$, then by alanine (11-13.4\%), and aspartic acid (7.4-13\%). 
Table 4. : Amino-acid composition (residues \%) of soluble organic matrices (SOM) in fine-grained carbonates from alternating carbonate-rich (a, c, g, e) and carbonate-poor (b, d, f) layers (see Fig. 2C)

\begin{tabular}{|c|c|c|c|c|c|c|c|}
\hline & \multicolumn{7}{|c|}{ Sediment layers } \\
\hline & $\mathbf{a}$ & $\mathbf{b}$ & c & d & $\mathbf{e}$ & f & g \\
\hline Asp & 9.9 & 13.04 & 12.2 & 9.76 & 7.83 & 9.47 & 7.36 \\
\hline Glu & 16.27 & 12.15 & 21.1 & 14.89 & 16.88 & 12.53 & 13.15 \\
\hline Lys & 1.34 & 1.22 & 0.98 & 3.93 & 7.45 & 4.59 & 1.80 \\
\hline Arg & 7.62 & 7.32 & 7.10 & 6.29 & 6.91 & 6.83 & 5.99 \\
\hline His & 4.40 & 5.15 & 2.43 & 4.83 & 2.80 & 4.65 & 4.98 \\
\hline Gly & 18.23 & 15.87 & 12.87 & 17.08 & 13.87 & 17.75 & 16.10 \\
\hline Ala & 13.37 & 12.57 & 12.92 & 12.72 & 12.17 & 10.96 & 13.03 \\
\hline Val & 7.17 & 6.77 & 7.27 & 6.37 & 4.83 & 6.28 & 6.98 \\
\hline Leu & 6.59 & 7.83 & 7.23 & 6.37 & 7.19 & 7.85 & 10.69 \\
\hline Ile & 4.16 & 4.46 & 4.70 & 3.77 & 3.01 & 3.99 & 6.92 \\
\hline Ser & 6.26 & 4.75 & 3.91 & 7.41 & 6.69 & 7.33 & 4.38 \\
\hline Thr & 0.86 & 3.01 & 2.11 & 1.70 & 0.00 & 0.47 & 0.49 \\
\hline Pro & 2.32 & 4.02 & 4.01 & 2.74 & 5.17 & 5.56 & 6.76 \\
\hline Tyr & 2.33 & 1.84 & 1.16 & 2.15 & 5.21 & 1.75 & 1.35 \\
\hline Phe & 0.00 & 0.00 & 0.00 & 0.00 & 0.00 & 0.00 & 0.00 \\
\hline
\end{tabular}

Amino-acid molecular compositions of insoluble matrices (Table 5) extracted from the carbonates are all dominated firstly by glycine (14.5-32\%), and glutamic acid (6.8-21.7\%), then by aspartic acid (3.2-15.2\%). They exhibit a range of compositional variation which is much higher than in other organic fractions, i.e., global sedimentary OM (Table 1, see also Fig. 5A) and pore waters (Table 2, see also Fig. 5B). 
Table 5. : Amino-acid composition (residues \%) of insoluble organic matrices (IOM) in fine-grained carbonates from alternating carbonate-rich (a, c, g, e) and carbonate-poor (b, d, f) layers (see Fig. 2C)

\begin{tabular}{|c|c|c|c|c|c|c|c|}
\hline & \multicolumn{7}{|c|}{ Sediment layers } \\
\hline & $\mathbf{a}$ & b & c & d & e & f & g \\
\hline Asp & 11.77 & 5.18 & 15.17 & 3.81 & 3.59 & 7.36 & 3.17 \\
\hline Glu & 17.36 & 14.00 & 21.71 & 10.44 & 11.37 & 9.46 & 6.00 \\
\hline Lys & 5.46 & 1.72 & 3.11 & 0.99 & 0.00 & 2.57 & 4.24 \\
\hline Arg & 4.38 & 5.94 & 5.84 & 8.45 & 6.19 & 12.13 & 5.39 \\
\hline $\mathrm{Hi}$ & 2.23 & 3.53 & 1.35 & 4.28 & 4.81 & 2.17 & 3.67 \\
\hline Gly & 15.01 & 21.70 & 14.48 & 22.47 & 29.64 & 32.07 & 25.21 \\
\hline Ala & 6.24 & 8.28 & 6.17 & 6.78 & 6.58 & 12.29 & 7.75 \\
\hline Val & 6.60 & 5.41 & 6.26 & 6.85 & 4.93 & 4.53 & 6.23 \\
\hline Leu & 12.83 & 8.77 & 9.44 & 10.60 & 10.24 & 4.54 & 12.99 \\
\hline Ile & 9.59 & 3.66 & 5.52 & 5.35 & 8.62 & 2.62 & 7.29 \\
\hline Ser & 4.33 & 10.02 & 4.94 & 11.38 & 6.29 & 5.21 & 8.03 \\
\hline Thr & 0.30 & 0.00 & 0.82 & 1.02 & 0.00 & 0.93 & 1.33 \\
\hline Pro & 1.64 & 9.77 & 3.62 & 4.40 & 7.21 & 3.46 & 5.04 \\
\hline Tyr & 2.25 & 2.01 & 1.37 & 3.17 & 0.54 & 0.67 & 2.91 \\
\hline Phe & 0.00 & 0.00 & 0.21 & 0.00 & 0.00 & 0.00 & 0.00 \\
\hline
\end{tabular}

In comparison with the amino-acid composition in the soluble matrices, the insoluble fraction turns out to be much richer in glycine and poorer in alanine (Table 5). Differences are smaller for other amino acids: soluble matrices are slightly enriched in aspartic and glutamic acids, and slightly depleted in leucine, isoleucine, and serine.

\subsection{Effect of dissolved pore water-macromolecules on the rate of calcium carbonate precipitation in experimental conditions}

Macromolecules dissolved (DMM) in pore waters extracted from the four youngest layers (a, $\mathrm{b}, \mathrm{c}, \mathrm{d})$ were tested for their capacity to induce carbonate precipitation. These layers are the least affected by diagenetic processes, at the same time as being the source of intense (layers $a, c)$ or weak carbonate precipitation (layers b, d). Two test series were carried out with total protein concentrations proportional to concentrations in pore waters extracted from these 4 layers (respectively 10 and 5 times lower than in pore waters, cf. Table 3 ). A third series with a constant amount of proteinaceous compounds $(10 \mu \mathrm{g})$ was used in order to compare the effects on the precipitation of (1) DMM concentrations (Fig. 4A, B), and (2) different compositions, as those displayed in the different layers (Fig. 4C). The aim of these experiments was to search for correlations existing between the amount and the molecular 
composition of dissolved organic compounds on one hand, and the intensity of calcium carbonate precipitation on the other hand.
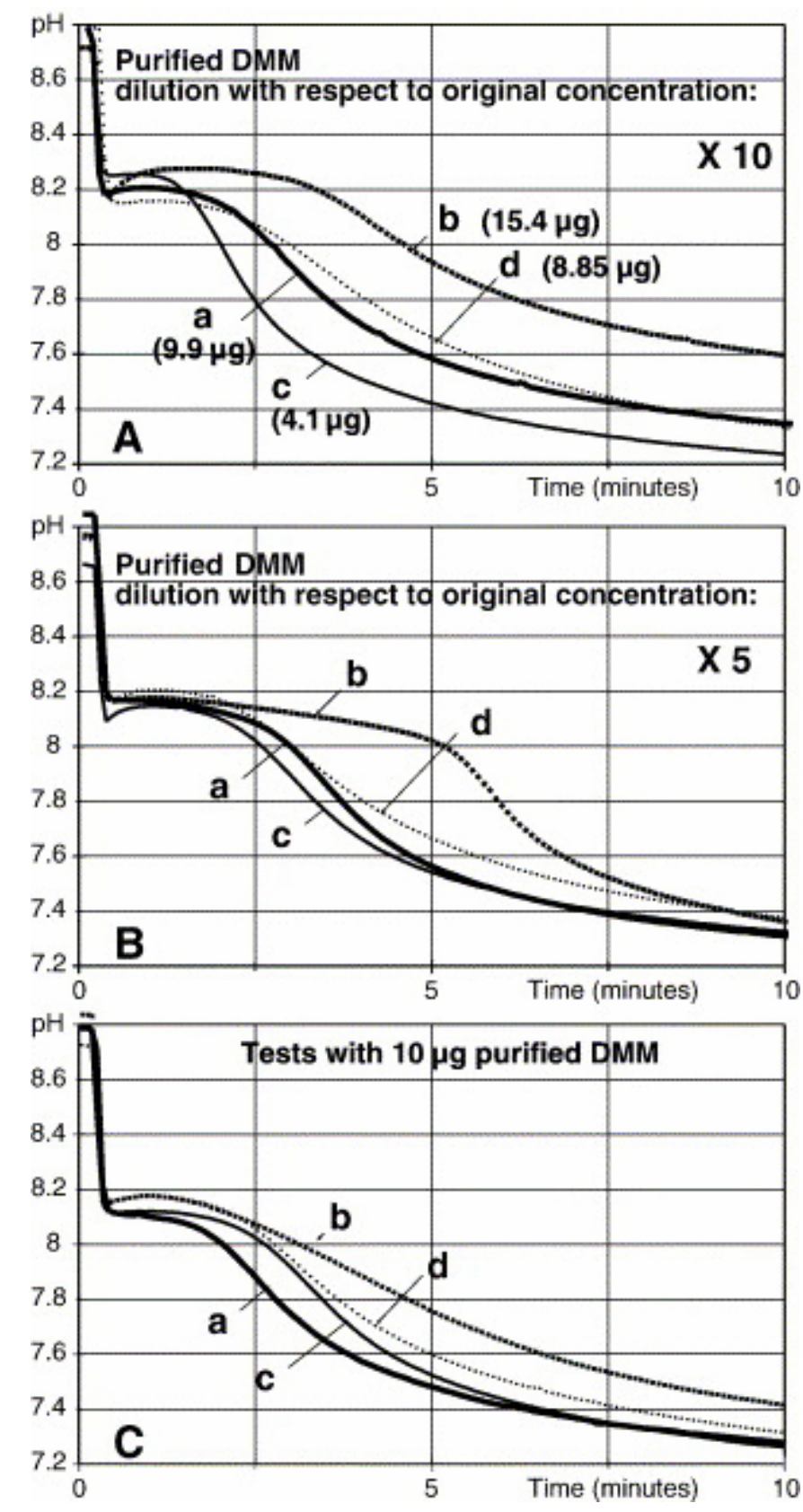

Fig. 4. In vitro tests of the influence of macromolecules (MW $>3 \mathrm{kDa}$ ) purified out of natural pore waters in sediment layers a, b, c and d, on calcium carbonate precipitation. (A, B) The amounts of dissolved organic macromolecules (DMM) used for the tests (indicated in $\mu \mathrm{g}$ ) are different according to their original concentration in each layer (dilution of the original concentration $\times 10$ in $\mathrm{A}, \times 5$ in $\mathrm{B}$ ). (C) Tests with a constant amount $(10 \mu \mathrm{g})$ of DMM from each of the four layers.

$\mathrm{pH}$ variations accompanying in vitro carbonate precipitation or inhibition, in the presence of purified soluble macromolecules are represented in Fig. 4. The curves exhibit two stages after the decrease of initial $\mathrm{pH}$ down to 8.2, resulting from the addition of $\mathrm{CaCl}_{2}$. The first one shows a quasi stable $\mathrm{pH}$, corresponding to a temporary inhibition of calcium carbonate precipitation. The solution remains clear throughout this phase. Its duration varies according 
to the intensity of Ca-complexation by the organic sample used. The following stage, characterised by a $\mathrm{pH}$ decrease, starts with the initiation of calcium carbonate precipitation. Recording of the $\mathrm{pH}$ shift shows different rates of calcium carbonate precipitation among the different tests.

Graphs A and B (Fig. 4) compare the effects of soluble macromolecules extracted from sediment layers a to $\mathrm{d}$, tested at different concentrations (the quantities used are indicated in brackets on the graphs). These concentrations are respectively 10 (Fig. 4A) and 5 (Fig. 4B) times lower than the primary concentrations of soluble protein-containing macromolecules $(\mathrm{MW}>3 \mathrm{kDa})$ in natural pore waters. The strongest inhibitory effects are observed in the tests carried out with organic matter in the pore waters of layers $b$ and $d$, corresponding to carbonate-poor layers, while the weakest inhibitory effects are observed with soluble organic matter extracted from pore waters of layers a and c, i.e., carbonate-rich sediment layers. At two different dilutions of the samples, the test using the highest concentration of organic matter exhibits the strongest inhibitory effect, proving that the quantity of organic compounds plays a key role in the inhibition, or promotion, of carbonatation processes.

The results of the four tests having used $10 \mu \mathrm{g}$ of these soluble macromolecules extracted from layers a to $\mathrm{d}$ are shown in Fig. 4C. The aim of these tests was to compare the influence of the different compositions of these macromolecules on calcificaton. Soluble macromolecules in pore waters extracted from layers $b$ and $d$ carbonate-poor layers) inhibit $\mathrm{CaCO}_{3}$ formation more strongly than molecules extracted from carbonate-rich layers a and $\mathrm{c}$, proving that the molecular composition of the proteinaceous soluble content has an effect on carbonate precipitation.

\subsection{Tracing the origin of the carbonate-linked organic matrices}

In order to trace the origin of the intramineral organic matter, the amino-acid compositions were compared in comparable fractions within carbonate minerals and in the sediment, i.e., respectively in the insoluble fractions in carbonates versus sedimentary organic matter and in the soluble fractions in carbonates versus sediment pore waters. Among several hypotheses regarding the behaviour of amino acids in the system associating carbonate minerals and organic matter, for example global incorporation or selective fractionation, the basic one is that the organic matter present in the environment where authigenic calcium carbonate is forming, can be trapped within mineral particules during their growth. If so, intramineral soluble and insoluble organic phases should display similar molecular compositions within and outside of the carbonate minerals.

\subsubsection{Insoluble organic fractions in carbonates (IOM) and sedimentary organic matter (Fig. 5A)}

Acidic amino acids are well represented in both materials, glutamic acid being dominant in carbonates and aspartic acid in the sedimentary organic matter. The distribution of basic amino acids-i.e., arginine and histidine-is also opposite, with arginine being common in carbonate matrices and histidine in the sedimentary organic matter. Glycine, leucine, isoleucine, serine, and proline are incorporated in the IOM of carbonates in much higher proportions than in the sedimentary organic matter, whilst alanine and valine are less concentrated in intramineral IOM than in cyanobacterially derived organic matter. Phenylalanine is quite absent in carbonate IOM. Such insoluble fractions are clearly not similar in carbonates and in the sedimentary organic matter. Fig. 5A also shows that the 
intramineral IOM is more variable in composition than the bulk sedimentary organic matter, whose approximately constant composition is in keeping with a cyanobacterial origin.
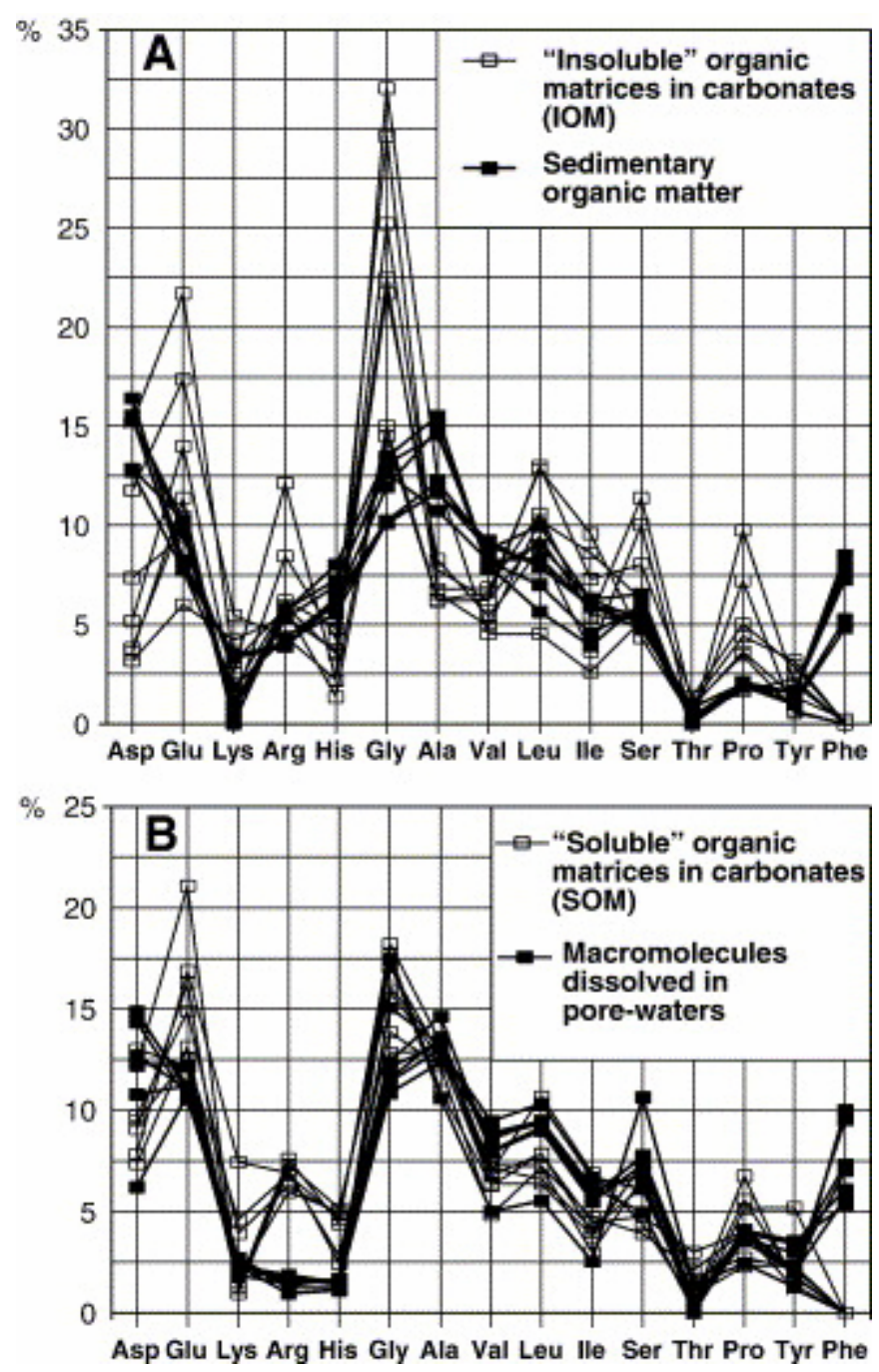

Fig. 5. Comparison of the amino-acid compositions of organic matter, out and within carbonate precipitates, in the seven sediment layers (a to g). (A) Insoluble fractions; (B) Soluble fractions.

\subsubsection{Soluble organic fractions in carbonates (SOM) and pore waters (Fig. 5B)}

If the aspartic acid concentration is similar (but nevertheless variable) in pore waters and in carbonate-linked SOM, glutamic acid is, on the contrary, strongly enriched in the latter. The three basic amino acids, lysine, histidine and arginine, are also more abundant in SOM of carbonates, while valine and phenylalanine are mainly restricted to pore waters. Other aminoacid concentrations (Ala, Leu, Ile, Ser, Thr, Pro, Tyr) do not vary significantly between both soluble phases, out and inside carbonates.

The composition of the intramineral soluble fraction (SOM) differs from that of pore waters, especially with regard to glutamic acid concentration although it is similar to the insoluble organic fraction of carbonates. In contrast to the insoluble fractions, the compositions of 
soluble fractions are not particularly variable, with the exception of diacidic amino acids (Asp and Glu).

A correct description and interpretation of the fractionation of amino acids in the four identified fractions (intra/extra carbonate, soluble/insoluble) needs, however, to take into account the variations in amino-acid contents resulting, not only from inheritage from cyanobacteria, but also from the diagenetic processes (microbiological, hydrogeochemical, petrographical, structural) under progress in the $5 \mathrm{~cm}$ thick sediment.

\subsection{Tracing the diagenetic evolution of amino acids in the sedimentary profile and carbonate precipitation}

The variations with depth of the relative amount of individual amino acids in the four different organic compartments (bulk sedimentary organic matter, pore waters, intramineral SOM and IOM) are illustrated in Fig. 6, Fig. 7, Fig. 8 and Fig. 9. The progressive variations with depth (time) are considered to be a function of diagenetic evolution, while variations related with the carbonatation, or non-carbonatation processes parallel to layers, are considered to be a result of actual organomineral processes.
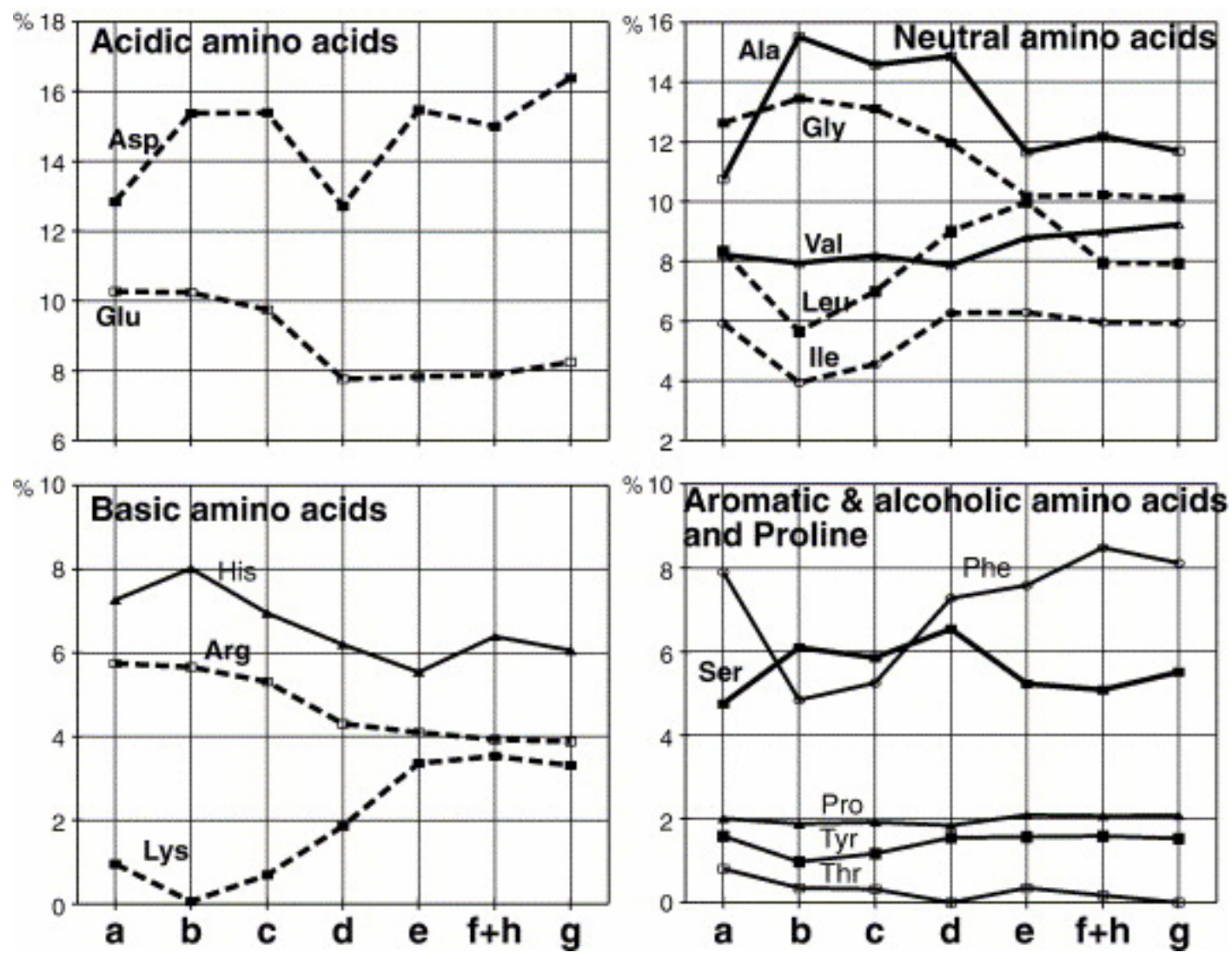

Fig. 6. Sedimentary, cyanobacterially derived organic matter: evolution of the relative concentration of individual amino acids in the successive, deeper and deeper sediment layers a to $g$ (layers $f$ and $h$ have been mixed because of the lack of material). Time- (or depth-) dependant variations in amino-acid concentrations are figured out by bold dotted lines. Those varying according to a high-low (or low-high) zigzag pattern in the successive layers, reliable with the carbonate-rich or carbonate-poor character of the layer, are represented by bold plain lines. Others: thin plain lines. 


\subsubsection{Sedimentary organic matter}

The relative compositions of cyanobacterially derived organic mats are very homogenous over all layers (Fig. 6). There is no clear evidence of a regular, increasing loss (i.e., degradation) or enhancement (i.e., secondary production) of particular amino acids through diagenetic processes. As an exception, the variation of aspartic acid content could exemplify the most regular time-dependant increase. For other amino acids, instead of an expected progressive decrease in concentrations, a compositional change intervenes at the limit between the top of the sedimentary body, including layers a, b, c, and the deeper one starting with layer d. Among such amino acids, glutamic acid, arginine and glycine exhibit a higher concentration in superficial layers $a, b$, c. Inversely higher concentrations of lysine, leucine and isoleucine are observed in the deeper sedimentary body (layers $\mathrm{d}, \mathrm{e}, \mathrm{f}+\mathrm{h}, \mathrm{g}$ ).

Alanine and serine proportions both vary according to a weakly expressed zigzag pattern that is anti-correlated with calcium carbonate.

\subsubsection{Pore water-proteinaceous macromolecules}

With the exception of aspartic acid, whose concentration varies sharply through successive layers, a general pattern of variation can be traced through the layers, as follows (Fig. 7): the slope of variation curves varies weakly across the most superficial (a to e) layers and more strongly, up or downward, in the deeper ones (e to g), suggesting diagenetic effects controlled by time or depth. Amino acids whose concentrations increase with depth, include phenylalanine, serine, glycine, lysine, threonine and glutamic acid. Those showing a depletion include arginine, leucine, isoleucine, valine and proline. The sharp variations of the aspartic acid concentration do not fit with the diagenesis hypothesis but rather reflect a relationship with carbonate precipitation, at least in the most superficial layers a to e. Despite a global decrease, tyrosine and proline have the highest concentrations in calcified layers. The total amount of proteinaceous macromolecules in the pore waters of the sediment layers globally decreases with depth, as for the exopolymer proportion that was found to decrease markedly with increasing depth by Mao Che et al. (2001). However, this decrease is not regular, the layers where calcification is weak being richer in soluble proteinaceous compounds than the pore waters of carbonate-rich layers (Fig. 3). 

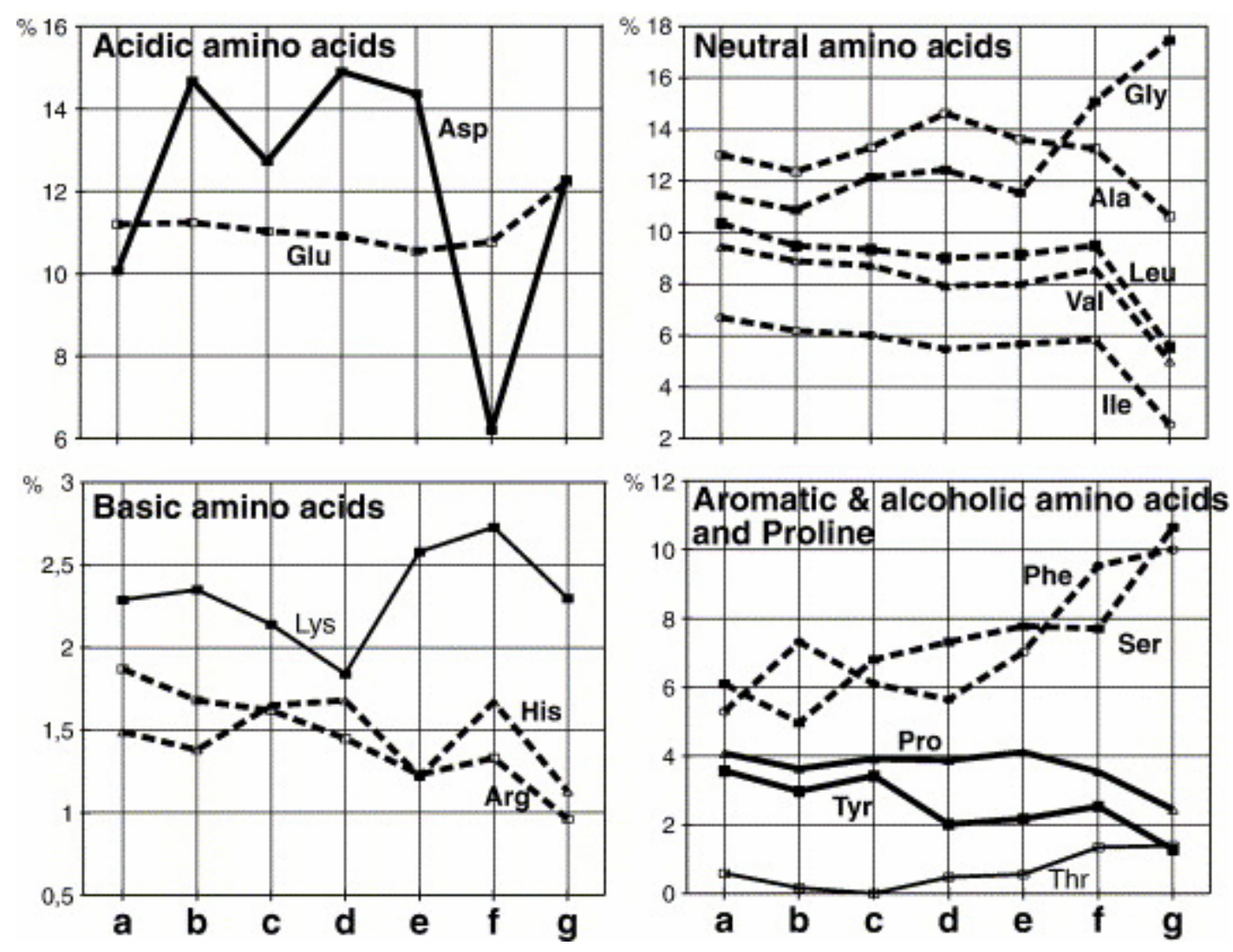

Fig. 7. Dissolved macromolecules (DMM, MW $>3 \mathrm{kDa}$ ) purified out of pore waters in layers a to g. Legend and symbols: see Fig. 6.

In experimental conditions, calcium carbonate precipitation does not start, or starts late and slowly, as shown in tests of carbonate precipitation performed with significant amounts of organic macromolecules purified from pore waters. As a first approach, this result is in agreement with those of previous studies, which showed that carbonate precipitation is inhibited by heavily loaded solutions (Tipping, 1994, Lebron and Suarez, 1996, Lebron and Suarez, 1998 and Hoch et al., 2000). However it is important to note that when the proteinaceous macromolecule concentration correlates with the alternance of carbonate-rich and -poor sediment layers, total organic carbon concentration varies independantly. In a fine scale study (scale in our study is the thickness of one layer, thus approximately $1 \mathrm{~cm}$ ) organic carbon cannot help in the interpretation of the influence of organic compounds on the calcification process because it includes many non-active biochemical compounds.

Evidence for the implication in calcification processes, even for the controlling capability of protein-containing molecules, is given by the in vitro experiments: at a constant experimental salinity, biochemical characters of extracted natural macromolecules definitely control the rate of calcium carbonate precipitation, including a total inhibition. The concentration of dissolved organic matter is important, but efficiency also depends on the composition of the dissolved molecules, making some proteins extremely active with regard to calcium carbonate formation. This experiment demonstrated the role of amino-acid composition and, in particular, that of diacidic amino-acid contents. 


\subsubsection{Carbonate-linked SOM}

The variation patterns of relative amino-acid concentrations differ much from the preceding ones, with a few number of amino acids whose concentrations are affected by time-dependant diagenesis (Fig. 8). The concentration of arginine decreases from the surface to deeper layers, leucine, isoleucine and proline increase. Other amino-acids concentrations display variations in clear relation with the occurrence, or the absence, of carbonate precipitation within the layer. Glutamic acid concentration (and to a lesser extent, alanine and valine) increases within carbonate-rich layers, whilst the concentration of glycine and histidine decreases. The concentrations of aspartic acid vary with respect to the carbonate-rich or carbonate-poor facies of the layer, with lower concentrations in the carbonate-rich layers (opposite to Glu variations), except in the layer c which contains an unexplained high concentration.
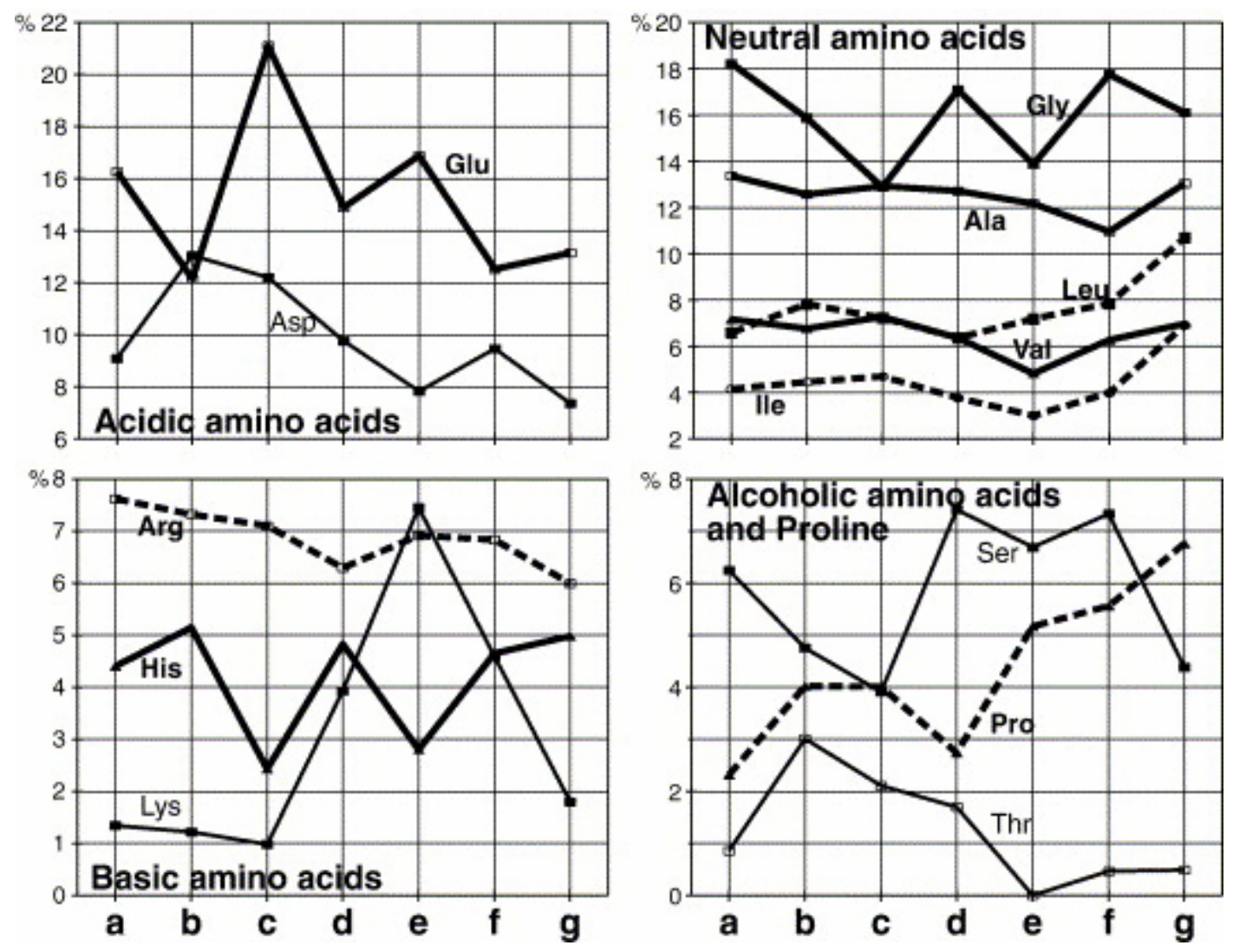

Fig. 8. Intramineral soluble organic matrices (SOM) of carbonate precipitates in layers a to g. Legend and symbols: see Fig. 6.

The weaker effect of time-dependant diagenesis on intramineral SOM compared to extramineral organic matter confirms the observation that bound organic matrices are protected against further transformation (Mitterer and Cunningham, 1985). The most visible change with depth is the decrease of the total amount of SOM, owing to the breakdown of peptide bonds that cause high molecular weight SOM-components to alter to small peptides (Gautret, 2000). However, this pattern is clearly overlaid by distinct amounts of intramineral $\mathrm{SOM}$ in carbonates that precipitated either in carbonate-rich layers, or in carbonate-depleted layers (Fig. 3). As a matter of fact, the SOM-rich carbonates precipitate in sediment layers where external conditions disfavor $\mathrm{CaCO}_{3}$ formation, while $\mathrm{CaCO}_{3}$ that precipitates in carbonate-rich layers is poorer in SOM. The former contains both a higher concentration of 
Asp and a lower concentration of Glu, compared with carbonate-linked SOM when $\mathrm{CaCO}_{3}$ precipitates heavily. Distinct amounts of SOM, combined with distinct concentrations of glutamic and aspartic acids, with respect to carbonatation intensity, indicate that external conditions favoring or preventing calcium carbonate precipitation also influence quality and quantity of intramineral matrices resulting from organomineralization processes.

\subsubsection{Carbonate-linked IOM}

Amino-acid compositions are different in the insoluble fraction of carbonates among the successive sediment layers (Fig. 9). Acidic amino acids (Glu and Asp) decrease globally with depth, whilst the basic lysine and the neutral glycine increase. However, for these amino acids, as for most of the others, variations in concentrations exhibit well marked contrasts related to the facies of the layers. Carbonate-rich layers are enriched in acidic amino acids (Glu and Asp), lysine, isoleucine and leucine, and depleted in arginine, histidine, serine and proline. Again the reason for such distinct compositions can be ascribed to the different protein and peptide fractionation processes that control organomineralization, together with external conditions that favor or inhibit $\mathrm{CaCO}_{3}$ precipitation.
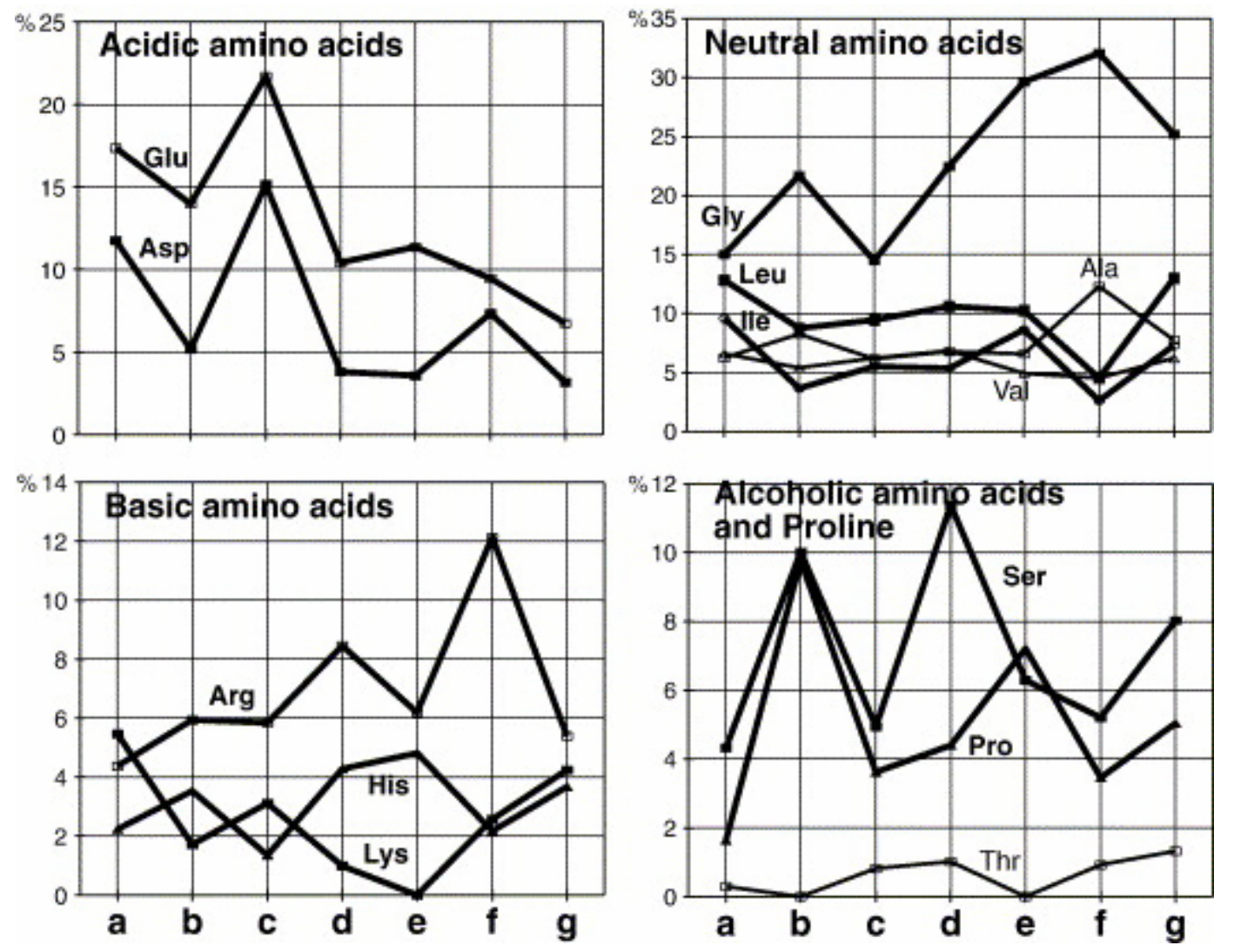

Fig. 9. Intramineral insoluble organic matrices (IOM) of carbonate precipitates in layers a to g. Legend and symbols: see Fig. 6.

\section{Discussion}

In both soluble and insoluble fractions, amino-acid compositions are different in comparable fractions, whether in carbonates or in extramineral organic matter. This suggests that the composition of the intramineral organic matter does not result from the simple entrapment of 
corresponding fractions out of the sedimentary organic matter. In marine cyanobacterial microbialites from the lagoon of Tikehau atoll (French Polynesia), a difference between amino-acid compositions of extra- and intramineral organic matter was also evidenced (Gautret et al., 2004). As in Rangiroa, the origin of the specific composition of the intramineral organic matter must therefore be traced to specific processes, such as organomineral interactions leading to the fractionation of amino acids, peptides and proteins in relation to the calcification processes. The efficiency of the molecular fractionation during, and by, organomineralization processes in different cyanobacterial environments of Polynesian atolls, such as lacustrine "kopara" deposits and marine round-shaped domes in lagoons, is evidenced by the specificity of the composition of soluble matrices associated with in situ-precipitated carbonates with regards to amino-acid spectrum. This is illustrated for example, i.e., by the high concentrations of aspartic acid (up to around 30\% in SOM associated with carbonates of lagoonal microbialites, Gautret et al., 2004), compared with the intramineral IOM or with the external, cyanobacterial organic matter.

The variations of amino-acid composition with depth differ in the distinct types of organic matter that compose the kopara deposit, out- and in carbonate precipitates. In the sedimentary organic matter, including degrading cyanobacterial sheathes and associated microbial communities, the distinction between the superfical half of the laminated sediment and the deeper one may be explained by the different taxonomic compositions of microbial communities, consisting in oxygenic phototrophic cyanobacteria in top layers and anoxygenic phototrophs, which sometimes cohabit with anaerobic heterotrophs in the layers below (Mao Che et al., 2001). But the contrast of oxygenic and anoxygenic layers is never sharp in kopara, due to the existence of microniches of one type within the other, in particular of anoxygenic microenvironments within top, oxic, layers (Défarge, 1983) due to the very small permeability to gas and solutions of the organic "cellular" network. Contrasting with our results on protein compositions, the analysis of carbohydrates in different Polynesian kopara ponds (including the pond R9 studied here) by Rougeaux et al. (2001) did not provide any significant difference in exopolymer carbohydrate compositions with depth.

Laboratory experiments of calcium carbonate precipitation in the presence of dissolved organic matter demonstrated the role of amino-acid composition and, in particular, that of diacidic amino-acid contents. Other studies (Gautret, 2000 and Gautret, 2001) showed that the size of such protein-rich molecules is also a key factor, as demonstrated by organic matrices extracted from older samples in a drilled coral core: with lower contents in aspartic acid, high molecular weight protein-rich matrices extracted from 1- to 10-year-old skeletal portions inhibit calcium carbonate precipitation much more strongly than low molecular weight compounds (short peptide chains resulting from the diagenesis of originally high molecular weight proteins) extracted $25 \mathrm{~cm}$ below the modern living surface of the colony, despite the fact that these compounds are enriched in acidic amino acids.

We assume that diacidic-protein rich macromolecules dissolved in sediment layer porewaters play a role that compares with those played by soluble aspartic-rich organic matrices in biomineralization processes. A number of explanations for the inhibition of mineralization by organic compounds can be proposed. One explanation is essentially "mechanistic": a heavy load of solubilized, negatively charged molecules adsorbs onto growing mineral surfaces resulting in the formation of an organic coating. This coating exerts an inhibiting effect on crystal growth (Addadi et al., 2001 and Mann, 2001). A second, "physico-chemical", explanation involves the buffering effect of acidic macromolecules. These are able first to fix $\mathrm{Ca}^{2+}$ ions, due to their calcium-binding ability, then to discharge free calcium in 
microenvironments when Ca-complexes demix. Trichet (1967) evoked such processes as being responsible for the carbonatation of "kopara" deposits and other sedimentary bodies on Mururoa atoll. First, calcium available in natural waters is complexed by organic anions derived from the degradation of cyanobacterial organic matter. Second, the biodegradation of these organic ligands, proteins, uronic acids, carbohydrates (Trichet, 1967 and Mao Che et al., 2001) liberates free divalent $\mathrm{Ca}$ and the alkaline level increases, leading to calcium carbonate precipitation. Recently again, Stal (2000) and Pearl et al. (2001) stated that freshly synthesized and intact extracellular acidic polysaccharides sequester $\mathrm{Ca}^{2+}$ by covalent binding to carboxylic groups and can thus inhibit calcification in the immediate surrounding of photosynthesizing cyanobacterial cells. It is expected that this bound $\mathrm{Ca}^{2+}$ becomes available during the biodegradation of these polysaccharides and that the enhanced free $\mathrm{Ca}^{2+}$ concentrations are responsible for calcification in conjunction with microbial heterotrophic activity. A parallel mechanism of anticalcification is proposed by Arp et al., 1998 and Arp et al., 1999. It is based on in situ observations of microbialite formation in alkaline lakes, in association with mucin-like fluids such as microbial extracellular polymeric substances (EPS) surrounding microbial cells and preventing them from lithification. The authors consider EPS as a Ca-buffer whose capacity has to be exceeded before nucleation is possible.

In the succession of sediment layers studied here ("kopara" deposits of Rangiroa), protein-rich macromolecules dissolved in pore waters are associated with conditions that are extremely active with respect to calcification (or alternatively anti-calcification): either they are rich in aspartic acid and highly concentrated in the environmental solution (in that case $\mathrm{CaCO}_{3}$ precipitation does not proceed), or they are poor in this amino acid and at the same time less abundant (in that case $\mathrm{CaCO}_{3}$ precipitation proceeds). In this case the different mechanisms mentioned above are most probably working together. Buffering capacity is the strongest when high amounts of aspartic-rich macromolecules are free in environmental solution. In parallel, as soon as calcium carbonate precipitation becomes possible, it is immediately slowed down due to the attraction of these negatively charged proteins by growing minerals, thus creating surface coatings which continue the anti-calcification action.

The consequence of such experimentally based results, as well as the correlation with the actual intensity of calcification in natural sediment layers, is crucial for discussing calcium carbonate balance or the formation of laminations in paleoenvironments. This proves that not only the changes in physicochemical conditions (e.g., evaporation, $p \mathrm{CO}_{2}, \mathrm{pH}$ ) or microbial metabolic pathways (e.g., sulfo-reduction) are able to favor calcium carbonate precipitation. Also the depletion, and/or the change in biochemical composition of reactive macromolecules in environmental solutions allow $\mathrm{CaCO}_{3}$ precipitation, when it is inhibited in comparable supersaturation conditions by solutions enriched with high molecular weight Asp-rich compounds, as part of dissolved organic matter (DOM). The dominant condition, with respect to the global concentration, and the richness in dicarboxylic amino acids, of dissolved macromolecules influences organomineralization processes, so that intramineral organic matrices exhibit distinct biochemical compositions. Due to the preferential preservation of $\mathrm{CaCO}_{3}$-bound organic matrices, we assume that amino-acid compositions of intramineral $\mathrm{OM}$ may provide usefull biomarkers of past environmental conditions of calcium carbonate precipitation.

\section{Conclusions}

(1) Mg-calcite organomineralization in kopara deposits (Pond R9, Rangiroa atoll, Tuamotu archipelago, French Polynesia) is described as a complex process including divalent cation 
$\left(\mathrm{Ca}^{2+}, \mathrm{Mg}^{2+}\right)$ complexation by Asp-Glu rich proteins, fractionation of the organic content dissolved in pore waters, and selective surface adsorption of insoluble, cyanobacterially derived organic matter. As a result of this process, fractionated organic matter associated with precipitated carbonates exhibits peculiar amino-acid compositions (soluble, SOM, or insoluble, IOM, organic matrix) which are distinct from those of dissolved or mucilaginous, sedimentary (cyanobacterially derived) organic matter.

(2) Primary biochemical processes prevail over secondary, time-dependant ones, in the processes controlling $\mathrm{Mg}$-calcite precipitation in these cyanobacterially derived sediments. Time-dependant transformations of protein-rich OM, commonly suspected to be the organic fraction the most susceptible to degradation (Hare, 1969), do not affect significantly the biochemical composition of organic matter in any of the different organic fractions studied. The most important compositional transformations are found in pore waters, however not within the five lately deposited layers, but essentially within the two deepest ones. Instead of other organic fractions (e.g., intramineral and dissolved in pore waters), the greatest compositional variations of sedimentary organic matter occur in the uppermost layer where cyanobacteria are still living, not in the oldest layers. The biochemical composition of intramineral proteinaceous matrices is preserved in all sediment layers.

(3) The key role played by organic molecules in active calcification processes is evidenced both in field and in experimental conditions. These molecules are present in the pore waters in each layer, and they are identified as soluble protein-rich macromolecules containing high concentrations of aspartic and/or glutamic acids, both carrying negatively charged carboxyl groups, which are able to bind dissolved $\mathrm{Ca}^{2+}$. The total amount of dissolved protein decreases globally with increasing depth, and clearly shows that deep layer pore water is strongly depleted in such molecules. However, overlaying the global time-dependant trend, the oscillating pattern of concentration in pore waters fits with the alternating presence-or absence-of dense calcification in the sediment. High contents of dissolved, Asp-rich organic macromolecules are found in pore water extracted from carbonate-poor layers. The inhibitor effect of such macromolecules on $\mathrm{CaCO}_{3}$ precipitation is verified in experimental conditions. Opposite characters typify carbonate-rich layers, i.e., a lower content organic macromolecules dissolved in pore water, a lower concentration of aspartic acid in these macromolecules, a lower inhibiting strength on experimental $\mathrm{CaCO}_{3}$ precipitation.

(4) Inhibiting processes cannot alone explain the numerous differences between amino-acid compositions of intramineral matrices in highly and weakly calcified layers, when such differences concern both soluble and insoluble compounds. Much higher complexity in organo-mineral interactions actually governs transfers and incorporation of organic compounds into the calcium carbonate lattice. If the high amounts of soluble matrix found within carbonates formed in anti-calcifying conditions (carbonate-poor layers) correspond to those coating mineral surfaces, selective adsorption could occur, for as yet unexplained reasons, resulting in different qualities of intramineral matrices depending on whether calcification processes are intense or not.

(5) The consequence of the inhibition of $\mathrm{CaCO}_{3}$ precipitation by dissolved organic macromolecules is crucial for discussing calcium carbonate balance or the formation of laminations in paleoenvironments. Furthermore, amino-acid compositions of protected $\mathrm{CaCO}_{3}$-bound organic matrices may provide useful biomarkers of past environmental conditions of calcium carbonate precipitation. 


\section{Acknowledgements}

This study is a contribution to the French National program PNRCO (Programme National Récifs Coralliens). The authors want to acknowledge Dr. Stjepko Golubic, an anonymous reviewer and the editor Bruce Sellwood for their constructive comments and Dr. Frances Westall who improved earlier versions of the manuscript. Thanks are extended to participants of the International Workshop on "Microbialites and microbial communities in sedimentary systems" held in Paris (September 6-9th, 2004) for exciting discussions.

\section{References}

Addadi et al., 2001 L. Addadi, M. Geva and S. Weiner, On how proteins interact with crystals and their effect on crystal formation, Z. Kardiol. 90 (2001) (Supl. 3), pp. 92-98.

Arp et al., 1998 G. Arp, J. Hofmann and J. Reitner, Microbial frabric formation in spring mounds ("microbialites") of alkaline salt lakes in the Badain Jaran Sand Sea, PR China, Palaios 13 (1998), pp. 581-592.

Arp et al., 1999 G. Arp, V. Thiel, A. Reimer, W. Michaelis and J. Reitner, Biofilm exopolymers control microbialite formation at thermal springs discharging into the alkaline Pyramid Lake, Nevada, USA, Sediment. Geol. 126 (1999), pp. 159-176.

Berner, 1968 R.A. Berner, Calcium carbonate concretions formed by the decomposition of organic matter, Science 159 (1968), pp. 195-197.

Berner, 1969 R.A. Berner, Chemical changes affecting dissolved calcium during the bacterial decomposition of fish and clams in sea water, Mar. Geol. 7 (1969), pp. 253-274.

Borman et al., 1982 A.H. Borman, E.W. De Yong, M. Huizinga, D.J. Kok, P. Westbroek and $\mathrm{L}$. Bosh, The role in $\mathrm{CaCO}_{3}$ crystallization of an acid $\mathrm{Ca}^{2+}$-binding polysaccharide associated with coccoliths of Emiliana huxleyi, Eur. J. Biochem. 129 (1982), pp. 179-183.

Burne and Moore, 1987 R.V. Burne and L.S. Moore, Microbialites: organosedimentary deposits of benthic microbial communities, Palaios 2 (1987), pp. 241-254.

Davies, 1970 G.R. Davies, Algal laminated sediments, Gladstone Embayment, Shark Bay, Western Australia. In: B.W. Logan et al., Editors, Carbonate Sediments and Environments, Shark Bay, Western Australia, Am. Assoc. Pet. Geol. Mem. vol. 13 (1970), pp. 169-205.

Défarge, 1983 Défarge, C., 1983. Contribution à l'étude géochimique et pétrologique des formations protostromatolithiques de Polynésie. Application à la connaissance des mécanismes de précipitation des carbonates de calcium au sein des matières organiques sédimentaires. Unpublished thesis, University of Orléans, France. 1 vol. text, 169 pp; 1 vol. plates, $21 \mathrm{pl}$.

Défarge and Trichet, 1985 C. Défarge and J. Trichet, First data on the biogeochemistry of kopara deposits from Rangiroa atoll. In: C. Gabrié, J.L. Toffart and B. Salvat, Editors, Proc. 5th Internat. Coral Reef Congr. Tahiti vol. 3 (1985), pp. 365-370. 
Défarge and Trichet, 1995 C. Défarge and J. Trichet, From biominerals to "organominerals": the example of the modern lacustrine calcareous stromatolites from Polynesian atolls, Bull. Inst. Océanogr. Monaco, Spec. Num. 14 (1995) (2), pp. 265-271.

Défarge et al., 1993 C. Défarge, J. Trichet, F.J. Sansone, J. Tribble, M. Robert and A.M. Jaunet, Further evidence for the participation of organic networks inherited form procaryotes in the development of microstructure and carbonatation of modern stromatolites. Paleontological inferences, C.R. Acad. Sci. Paris Ser. II 316 (1993), pp. 1107-1114.

Défarge et al., 1994a C. Défarge, J. Trichet and A. Couté, On the appearance of cyanobacterial calcification in modern stromatolites, Sediment. Geol. 94 (1994), pp. 11-19.

Défarge et al., 1994b C. Défarge, J. Trichet, A. Maurin and M. Hucher, Kopara in Polynesian atolls: early stages of formation of calcareous stromatolites, Sediment. Geol. 89 (1994), pp. 923.

Défarge et al., 1996 C. Défarge, J. Trichet, A.M. Jaunet, M. Robert, J. Tribble and F. Sansone, Texture of microbial sediments revealed by cryo-scanning electron microscopy, J. Sediment. Res. 66 (1996), pp. 935-947.

Disnar and Trichet, 1981 J.R. Disnar and J. Trichet, Etude expérimentale de la fixation de métaux par un matériau sédimentaire actuel d'origine algaire-I. Isolement, purification et caractérisation de la matière organique, Geochim. Cosmochim. Acta. 45 (1981), pp. 353-362. Abstract

Gautret, 2000 P. Gautret, Les matrices organiques intrasquelettiques des scleractiniaires récifaux: évolution diagénétique précoce de leurs caractéristiques biochimiques et conséquences pour les processus de cimentation, Geobios 33 (2000) (1), pp. 73-78.

Gautret, 2001 P. Gautret, Biochemical features of intraskeletal organic matrices within sponge and coral aragonites: implication for diagenetic pathways, Bull. Tohoku Univ. Mus. 1 (2001), pp. 155-163.

Gautret et al., 2004 P. Gautret, G. Camoin, S. Golubic and S. Sprachta, Biochemical control of calcium carbonate precipitation in modern lagoonal microbialites, Tikehau Atoll, French Polynesia, J Sediment Res. 74 (2004), pp. 462-478.

Golubic, 1973 S. Golubic, The relationship between blue-green algae and carbonate deposits. In: N.B. Carr and B.A. Whitton, Editors, The Biology of Blue-green Algae, Blackwell Scientific Publications, Oxford, U.K. (1973), pp. 434-472.

Golubic, 1976 S. Golubic, Organisms that build stromatolites. In: M.R. Walter, Editor, Stromatolites, Development in Sedimentology vol. 20, Elsevier, Amsterdam (1976), pp. 113126.

Greenfield, 1963 L.J. Greenfield, Metabolism and concentration of calcium and magnesium and precipitation of calcium carbonate by a marine bacterium, Ann. N.Y. Acad. Sci. 109 (1963), pp. 23-45. 
Hare, 1969 P.E. Hare, Geochemistry of proteins, peptides and amino acids. In: G. Eglinton and M.T.J. Murphy, Editors, Organic Geochemistry, Springer-Verlag, Berlin (1969), pp. 438463.

Hoch et al., 2000 R.A. Hoch, M.M. Reddy and G.R. Aiken, Calcite crystal growth inhibition by humic substances with emphasis on hydrophobic acids from Florida Everglades, Geochim. Cosmochim. Acta. 64 (2000), pp. 61-72.

Krumbein, 1979 W.E. Krumbein, Calcification by bacteria and algae. In: P.P.A. Trudinger and D.J. Swaine, Editors, Biochemical Cycling of Mineral Forming Elements, Elsevier, Amsterdam (1979), pp. 47-68.

Krumbein et al., 1977 W.E. Krumbein, Y. Cohen and M. Shilo, Solar Lake (Sinai). 4. Stromatolotic cyanobacterial mats, Limnol. Oceanogr. 22 (1977), pp. 635-656.

Lebron and Suarez, 1996 I. Lebron and D.L. Suarez, Calcite nucleation and precipitation kinetics affected by dissolved organic matter at $25{ }^{\circ} \mathrm{C}$ and $\mathrm{pH}>7.5$, Geochim. Cosmochim. Acta. 60 (1996), pp. 2765-2776.

Lebron and Suarez, 1998 I. Lebron and D.L. Suarez, Kinetics and mechanisms of precipitation of calcite as affected by $\mathrm{PCO}_{2}$ and organic ligands at $25{ }^{\circ} \mathrm{C}$, Geochim. Cosmochim. Acta. 62 (1998), pp. 405-416.

Logan et al., 1964 B.W. Logan, R. Rezak and R.N. Ginsburg, Classification and environmental significance of algal stromatolites, J. Geol. 72 (1964), pp. 68-83.

Mann, 2001 S. Mann, Biomineralization: Principles and Concepts in Bioinorganic Materiels Chemistry, University Press, Oxford, U.K. (2001) 198 pp..

Mao Che et al., 2001 L. Mao Che, S. Andréfouët, V. Bothorel, M. Guezennec, H. Rougeaux and J. Guezennec et al., Physical, chemical, and microbiological characteristics of microbial mats (Kopara) in the South Pacific atolls of French Polynesia, Can. J. Microbiol. 47 (2001), pp. 994-1012.

Merz, 1992 M. Merz, The biology of carbonate precipitation by cyanobacteria, Facie 26 (1992), pp. 81-102.

Merz et al., 1995 M. Merz, W.R. Schlue and H. Zankl, pH-measurements in the sheaths of calcifying filamentous cyanobacteria, Bull. Inst. Océanogr. Monaco. Spec. Num. 14 (1995) (2), pp. 281-289.

Mitterer and Cunningham, 1985 R.M. Mitterer and J.R. Cunningham, The interaction of natural organic matter with grain surfaces: implications for calcium carbonate precipitation, Soc. Econ. Paleontol. Mineral. 86 (1985), pp. 16-31.

Monty, 1965 C. Monty, Recent algal stromatolites in the winward lagoon, Andros Island, Bahamas, Ann. Soc. Geol. Belg. 88 (1965), pp. 269-277.

Pearl et al., 2001 H.W. Pearl, T.F. Steppe and P. Reid, Bacterially mediated precipitation in marine stromatolites, Environ. Microbiol. 3 (2001), pp. 123-130. 
Reid and Browne, 1991 R.P. Reid and K.M. Browne, Intertidal stromatolites in a fringing Holocene reef complex in the Bahamas, Geology 19 (1991), pp. 15-18.

Riding, 1991 R. Riding, Calcified cyanobacteria. In: R. Riding, Editor, Calcareous Algae and Stromatolites, Springer-Verlag, Berlin (1991), pp. 55-87.

Rougeaux et al., 2001 H. Rougeaux, M. Guezennec, L. Mao Che, C. Payri, E. Deslandes and J. Guezennec, Microbial communities and exopolysaccharides from Polynesian mats, Mar. Biotechnol. 3 (2001), pp. 181-187.

Sagemann et al., 1999 J. Sagemann, S.J. Bale, D.E.G. Briggs and R.J. Parkes, Controls on the formation of authigenic minerals in association with decaying organic matter: an experimental approach, Geochim. Cosmochim. Acta. 63 (1999), pp. 1083-1095.

Stal, 2000 L.J. Stal, Cyanobacterial mats and stromatolites. In: B.A. Whitton and M. Potts, Editors, The Ecology of Cyanobacteria, Kluwer Academic Publisher, Dordrecht (2000), pp. 61-120.

Thompson and Ferris, 1990 J.B. Thompson and F.G. Ferris, Cyanobacterial precipitation of gypsum, calcite, and magnesite from natural alkaline lake water, Geology 18 (1990), pp. 995998.

Tipping, 1994 E. Tipping, WHAMC - a chemical equilibrium model and computer code for waters, sediments, and soils incorporating a discrete site/electrostatic model for ion-binding by humic substances, Comput. Geosci. 20 (1994), pp. 973-1023.

Trichet, 1967 J. Trichet, Essai d'explication du dépôt d'aragonite sur des substrats organiques, C.R. Acad. Sci. Paris Ser. D 265 (1967), pp. 1464-1467.

Trichet and Défarge, 1995 J. Trichet and C. Défarge, Non-biologically supported organomineralization, Bull. Inst. Océanogr. Monaco. Spec. Num. 14 (1995) (2), pp. 203-236.

Trichet and Défarge, 1999 J. Trichet and C. Défarge, Sedimentary organic matter derived from cyanobacteria: composition, structure and properties of kopara deposits, Bull. Inst. Océanogr. Monaco. Spec. Num. 19 (1999), pp. 203-208.

Visscher et al., 2000 P. Visscher, P. Reid and B.M. Bebout, Microscale observations of sulfate reduction: correlation of microbial activity with lithified micritic laminae in modern marine stromatolites, Geology 28 (2000), pp. 919-922.

Westbroek et al., 1994 P. Westbroek, B. Buddemeier, M. Coleman, D.J. Kok, D. Fautin and L. Stal, Strategies for study of climate forcing by calcification, Bull. Inst. Océanogr. Monaco. Spec. Num. 14 (1994) (2), pp. 203-236.

Wheeler et al., 1981 A.P. Wheeler, J.W. George and C.A. Evans, Control of calcium carbonate nucleation and crystal growth by soluble matrix of oyster shell, Nature 212 (1981), pp. 1397-1398. 
Yates and Robbins, 1999 K.K. Yates and L. Robbins, Radioisotope tracer studies of inorganic carbon and $\mathrm{Ca}$ in microbially derived $\mathrm{CaCO}_{3}$, Geochim. Cosmochim. Acta. 63 (1999), pp. 129-136. 